\title{
COMPARING PERFORMANCE OF FIXED AND VARIABLE AREA SAMPLING PLOTS IN IRANIAN SUB-HUMID FORESTS
}

\author{
AlJ ANPOUR, A.* - JABBARI, K. - ESHAGHI RAD, J. -SEYEDI, N. - PAKGOHAR, N. \\ Faculty of Natural Resources, Urmia University, Urmia, Iran \\ *Corresponding author \\ e-mail:a.alijanpour@urmia.ac.ir,ahmad.alijanpour@yahoo.com
}

(Received $9^{\text {th }}$ Feb 2018; accepted $2^{\text {nd }}$ May 2018)

\begin{abstract}
In this study, two inventory methods, including use of plots with $300 \mathrm{~m}^{2}$ fixed-area and Relascope with variable-area plots were compared to evaluate biodiversity, quantitative and qualitative characteristics of Arasbaran forest stands in the North West of Iran. For this purpose, 58 sample plots were specified using $100 \mathrm{~m} \times 100 \mathrm{~m}$ regular randomized grid and tree characteristics were measured by two inventory methods. In each plot, the quantitative characteristics including diameter at breast height (DBH), basal area at breast height, tree number (density) and volume per hectare, sampling time and the qualitative characteristics such as percentage of species composition, health and origin of trees were recorded. Species richness, Shannon Weiner diversity and Simpson evenness indices were calculated for each sample plot. Independent t-test was applied for comparing the means of quantitative characteristics and biodiversity indices between the two methods. The results indicated that the quantitative characteristics are significantly different between two methods, whereas, no significant differences were observed in richness, biodiversity indices and qualitative characteristics. Average inventory duration in the fixed-area plot method (706.10 s) was considerably higher than that of the variable-area plots method with Relascope (485.91 s). The square of sampling error by inventory time $\left(\mathrm{T} \times \mathrm{E} \%{ }^{2}\right)$ index was used to evaluate the two methods precisely. This coefficient was less for volume per hectare and basal area at breast height per hectare in the variable-area plot method.
\end{abstract}

Keywords: Arasbaran forests, species diversity, fixed area plot, relascope, quantitative characteristics

\section{Introduction}

Arasbaran area is a crossing zone among multi-habitats due to its vegetative elements related to numerous climates. Existence of specific climatic conditions, high biodiversity, presence of rare plant and animal species as well as existence of vegetative elements related to various climates are factors distinguishing these forests from other regions (Sagheb Talebi et al., 2005). Stand structure and species diversity are two important ecological and functional features of forest ecosystems (Pretzch, 1997), affecting the landscape beauty and recreational value of the forest ( $\mathrm{Su}$ et al., 2012). According to the sustainable management criteria, maintaining and enhancing diversity are important factors in forest conservation (Nath et al., 2009). Protecting the natural ecosystems and biodiversity of Arasbaran forests is necessary due to its importance and status in a variety of aspects. They include species diversity, vital effects on water balance of the Aras River, preservation of biological reserves, impact on climate purification, preventing soil erosion, providing ecotourism values and achieving sustainable development (Mohammad Zadeh et al., 2014). Monitoring this valuable resource is the most important way to reach a management model and maintain ecosystem biodiversity, which can be achieved by quantitative and qualitative forest inventory and understanding the forest community dynamics, making possible subsequent planning (Eshaghi Rad et al., 2003; Islam et al., 2015; Motz et al., 2010; Hassanzad Navroodi et al., 2015). However, foresters often face problems with 
choosing the right method to measure and obtain accurate scientific information on biodiversity and forest structure (Pique et al., 2011).

An appropriate measurement method is one that offers reasonable information about the inventory area with suitable accuracy and cost (Parker, 1979; Husch et al., 1982; Avery and Burkhart, 2015). Accordingly, decision making on the measured variable and the appropriate measurement method is necessary (Pique et al., 2011). In forest inventory, various methods are used to design the sampling plots that are generally divided into two groups: sample plots with fixed area and sample plots with variable area (Zobeyri, 2007). Relascope is suggested for variable-area plot sampling method which is also known as n-tree sampling methodology (Bitterlich, 1984). In the fixedarea plot sampling method, the probability of selecting each one of the trees is the same within the sample unit, but in contrast with the variable-area plots method, the trees have a selection chance depending on their dimensions (Bitterlich, 1984; Ducey, 1999). In sampling with variable-area plot, it is attempted to increase sampling efficiency by overcoming the drawbacks associated with the fixed-area plot sampling method (Sheil et al., 2003). Zare et al (2016) selected a wild Pistachio stand in Fars Province of Iran where in a $100 \times 100 \mathrm{~m}^{2}$ grid, 46 sample points and six single-distance sampling methods were applied. In general, nearest single-distance methods were efficient enough to estimate the biometric characteristic of wild Pistachio trees precisely and accurately.

Relascope is a multipurpose device for measuring samples with variable area that is used by researchers for estimating biodiversity and stand structure (Barabesi and Fattoriu, 1999; Motz et al., 2010). In the Relascope method, the probability of choosing trees is proportional to their dimension and size (Piqueet al., 2011). In order to determine the best sampling method, several studies have been conducted. Some of these studies have introduced fixed-area plot sampling methods as the suitable ones for estimating quantitative, qualitative information and biodiversity (Motz et al., 2010). Whereas in the others, the sampling method with variable area or sample line has been introduced as the superior method (Eshaghi Rad et al., 2003; Alijanpour et al., 2003; Henttonen and Kangas, 2015).

Fallah et al. (2000) compared two sampling methods with fixed-area plots (10 acre) and variable-area plots (Relascope) in Loveh - Gorgan oak forests using characteristics including number of trees per hectare, basal area per hectare and time required for data recording. Results showed that the sampling method with 10 acre area was more suitable for the forest inventory. In another study, two methods of measuring with fixedarea plot and Relascope were used to study quantitative variables in northern Spain. It was found that the use of Relascope has a faster estimation of variables compared to the fixed-area sampling method. This means that although the Relascope is a costly sampling instrument, it significantly reduces the cost of inventory and, if needed, facilitates increased sampling density for a specific budget (Pique et al., 2011). Despite numerous studies in the Arasbaran region using sampling with fixed-area plots and sample line (Alijanpour et al., 2009; Moradi et al., 2015), the use of Relascope has not yet been used to measure quantitative and qualitative characteristics and species diversity.

This study intends to use two methods, namely circular sample plots with an area of three acre and Relascope (Band number of 2) to estimate the diversity of species, quantitative and qualitative characteristics (by the criterion of integrating inventory error and plot sampling time in the forest stands of the Kaleibar Chay watershed (Armeni Olan) of the Arasbaran region. 


\section{Material and methods}

\section{Study area}

The Armeni Olan forests unit, with an area of 60 hectares, located at longitude of $46^{\circ}$ $45^{\prime} 7^{\prime \prime}$ to $46^{\circ} 45^{\prime} 52^{\prime \prime}$ East, and latitude of $38^{\circ} 55^{\prime} 43^{\prime \prime}$ to $38^{\circ} 56^{\prime} 22^{\prime \prime}$ North was selected for this research (Fig. 1).

Annual rainfall is about 500-600 mm. Relative humidity in June reaches its highest level, about $85 \%$. Arasbaran dense forests are located at altitudes of 1000 to $1600 \mathrm{~m}$ above sea level (Alijanpour, 2011). The climate condition of the region is moderate semi-humid with cool and dry summers based on the De Martonne formula. The soil in the forest areas is mostly of brown and calcareous brown types. These soils are located on top of hard rock limestone, marl and sandstone (Alijanpour, 2011).

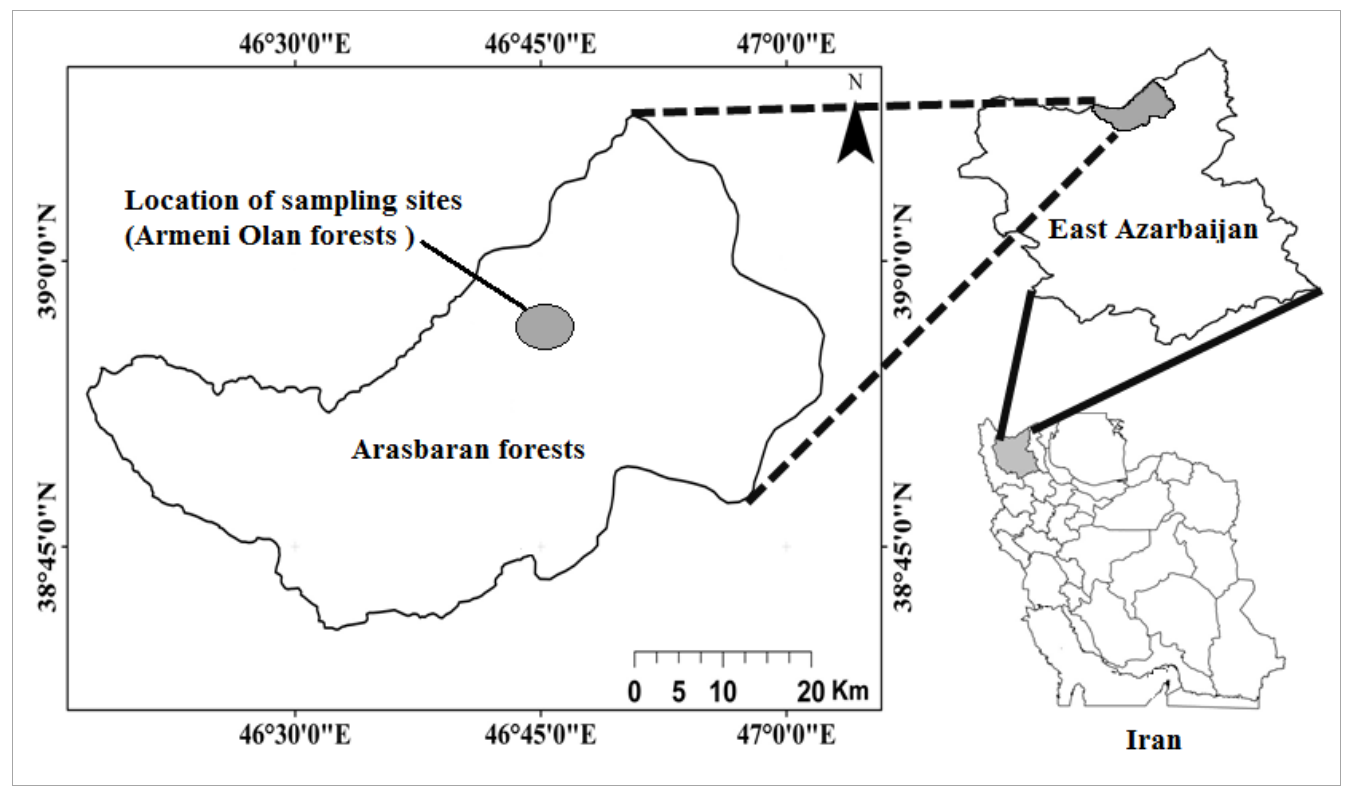

Figure 1. Location of sampling site in Arasbaran forests

\section{Research methodology}

Initially, a 60-hectare area was selected in the forest area. For the sampling of plots, a regular randomized grid system with $100 \times 100 \mathrm{~m}$ dimensions was established.

Then, 58 points were specified on the map (1:10,000 scale) at the intersections of the network sides as plot centers. According to the conducted field survey and the previous studies carried out in the forest stands of the Arasbaran region and the placement of 1510 trees in the sample, the area and shape of sample plots were decided to be circular fixed-area of three acre (Alijanpour et al., 2009; Alijanpour et al., 2011). At first, the general characteristics of each sampling plot location were recorded. Then, diameter at breast height $(\mathrm{DBH})(\mathrm{cm})$ was measured using Calliper (Ushikata, Japan). Finally, the type of species, origin, and quality of trees were recorded.

The trees were studied in terms of the origin (seed regeneration stems and coppiced stems) as well as health status of the stem (healthy and unhealthy trees). Individuals infested by fungi or insect and also decayed trees were considered unhealthy. Then, the heights $(\mathrm{m})$ of five trees, comprising of four trees close to the center of the sample plot 
in the four geographic directions, and one tree as the thickest one were measured (Suunto clinometer, Finland) in the sampling plot. Sampling time was also recorded by stopwatch. In order to record data with Relascope, based on the initial controlling of Band No. 2 and considering the placement of 10-15 trees in the sample plot, the quantitative and qualitative characteristics of the trees were measured (Spiegel Relascope, Austria) in accordance with the instructions for using the Relascope device (Avery and Burkhart, 2015). In this method, the sampling time of the plots was also recorded.

The measured DBH in each variable area-plot was entered into Microsoft Excel 2013 to calculate the basal area per hectare of fixed-area plot samples by using Equation 1.

The coefficient of basal area for Band 2 of Relascope was used to calculate basal area per hectare (Avery and Burkhart, 2015).

$$
g=\frac{\pi}{4} \times d^{2}
$$

Where $\mathrm{g}$ is the basal area at breast height $\left(\mathrm{m}^{2}\right)$ and $\mathrm{d}$ is DBH $(\mathrm{m})$.

In order to calculate the volume in a sample plot with fixed-area, it is necessary to use a local volume table, which unfortunately has not been yet provided for Arasbaran forest stands.

Therefore, the relationship between DBH and the measured heights of the trees in the fixed area plot (five stems per plot) was used to calculate such a table. Based on the calculated height graph and the estimation of the height of each diameter class, its volume was estimated using Equation 2.

Next, the volume in the sample plot and the volume per hectare of trees in the sample plot were calculated (Zobeyri, 2007).

$$
V=0.4 \times d^{2} \times h
$$

Where $\mathrm{V}$ is tree volume $\left(\mathrm{m}^{3}\right), \mathrm{d}$ is $\mathrm{DBH}$ and $\mathrm{h}$ is tree height $(\mathrm{m})$.

To calculate the volume per hectare for each sample plot in the Relascope method, the trees were arranged in diameter classes of $1 \mathrm{~cm}$ and the coefficient per hectare was calculated for each of the diameter classes.

Taking into account the selected strip coefficient for sampling and diameter class, the coefficient in hectare for each diameter class was calculated (Avery and Burkhart, 2015). Equation 3 was used to calculate the coefficient per hectare.

$$
\mathrm{F}=10000 \div\left(d^{2} \times f^{2} \times \pi\right)
$$

Where $F$ is the coefficient per hectare, $d$ is the diameter of each class $(m), f$ is the coefficient of each strip for the tree (in this study, tape number 2 was used for the sampling and the coefficient of the strip was 35.35).

Then, considering the number of trees in each diameter class, the number per hectare was calculated and, taking into account the volume of each class (by the volume table prepared in this study), the volume per hectare was calculated for each sample plot.

For statistical analysis of the species type data, DBH, quality, origin, slope and sampling time for each sample were entered in the SPSS software version 22 and, the 
normal distribution of the quantitative data was evaluated using the KolmogorovSmirnov test.

The calculated mean DBH, basal area at breast height, volume and time for each of sample plot in two methods of sampling with fixed-area and variable-area plots were compared by using the independent t-test. Origin, species composition and quality of species were compared by the Chi-Square test.

In addition, the species frequency data were used in each sample plot to calculate the species evenness and diversity indices.

Species richness, Simpson diversity index, Shannon Wiener diversity and evenness indices for each plot were calculated using the PC-ORD software version 5. Then, the obtained indices were compared with the independent t-test using SPSS version 22.

Finally, in order to evaluate the two methods of inventory, Equation 4 was used, where $\mathrm{E} \%$ is the standard error of estimation at the specified confidence level and $(\mathrm{T})$ is the sampling time (Husch et al., 1982).

$$
\mathrm{A}=(\mathrm{E} \%)^{2} \times \mathrm{T}
$$

\section{Results}

\section{Quantitative characteristics of the studied stand}

Obtained mean, standard error and percentage of standard error for DBH, number per hectare, basal area at breast height per hectare, volume per hectare and height of trees from 58 sampling plots with fixed and variable-areas (Relascope) are provided in Table 1. Based on this table, mean $\mathrm{DBH}$, basal area at breast height, number per hectares and volume per hectare in the variable-area plots sampling method is higher than fixed-area plots.

\section{Qualitative characteristics of the study stand}

\section{Percentage of mixture of species}

As shown in Table 2, in the method of using plots with fixed-area, Carpinus betulus had the highest frequency $(76.6 \%)$ and in the sampling method with variable-area plots, this species, with $74.4 \%$, was the most frequent species in the stand.

\section{The origin of the trees}

The results of sampling with fixed-area plots showed that $86.3 \%$ of the trees in this stand were coppiced stems and $13.7 \%$ were seed regeneration stems. On the other hand, the results of sampling plots with variable-area showed that $84.1 \%$ of the trees in this stand were coppiced stems and $15.9 \%$ were seed regeneration stems (Fig. 2).

\section{Tree health}

Another characteristic studied for the trees was the health of the trees whose DBH values were measured.

From the total number of trees measured by the fixed-area plots sampling method, about $91.2 \%$ were healthy and $8.8 \%$ were unhealthy. While, Sampling by variable-area plots yielded $92.7 \%$ healthy and $7.3 \%$ unhealthy trees (Fig. 3). 


\section{Comparison of quantitative and qualitative characteristics of the studied stand in the two methods}

The t-test results between the two inventory methods for parameters including mean diameter at breast height, mean basal area per hectare and average volume per hectare showed that there were significant differences at the $95 \%$ probability level (Table 1).

In addition, according to the Chi-Square test, it was found that the parameters including percentage of species composition, origin and health of the stems had no significant difference between the two inventory methods at $95 \%$ probability (Table 3 ).

Table 1. Quantitative characteristics of the studied stand and t-test results

\begin{tabular}{|c|c|c|c|c|c|c|}
\hline Variables & $\begin{array}{c}\text { Method of } \\
\text { sampling } \\
\end{array}$ & Mean & $\begin{array}{c}\text { Standard } \\
\text { error }\end{array}$ & $\begin{array}{c}\text { \% Standard } \\
\text { error }\end{array}$ & $\mathbf{t}$ & Significance \\
\hline $\mathrm{DBH}(\mathrm{cm})$ & $\begin{array}{c}\text { Fixed area plot } \\
\text { Relascope }\end{array}$ & $\begin{array}{l}12.34 \\
13.83 \\
\end{array}$ & $\begin{array}{l}0.19 \\
0.24 \\
\end{array}$ & $\begin{array}{r}3.08 \\
3.47 \\
\end{array}$ & -5.027 & $0.000^{*}$ \\
\hline $\begin{array}{c}\text { Basal area } \\
\left(\mathrm{m}^{2} / \mathrm{ha}\right)\end{array}$ & $\begin{array}{c}\text { Fixed area plot } \\
\text { Relascope }\end{array}$ & $\begin{array}{l}12.41 \\
14.96\end{array}$ & $\begin{array}{c}0.69 \\
0.6\end{array}$ & $\begin{array}{l}11.12 \\
8.02\end{array}$ & -2.805 & $0.006^{*}$ \\
\hline $\begin{array}{l}\text { Volume } \\
\left(\mathrm{m}^{3} / \mathrm{ha}\right)\end{array}$ & $\begin{array}{c}\text { Fixed area plot } \\
\text { Relascope }\end{array}$ & $\begin{array}{l}64.77 \\
74.96 \\
\end{array}$ & $\begin{array}{c}4.2 \\
3.26 \\
\end{array}$ & $\begin{array}{c}12.97 \\
8.70 \\
\end{array}$ & -1.93 & $0.057^{*}$ \\
\hline \multirow[t]{2}{*}{$\begin{array}{l}\text { Number of } \\
\text { trees }(\mathrm{N} / \mathrm{ha})\end{array}$} & $\begin{array}{c}\text { Fixed area plot } \\
\text { Relascope }\end{array}$ & $\begin{array}{c}939.65 \\
1195.27\end{array}$ & $\begin{array}{l}44.37 \\
54.62\end{array}$ & $\begin{array}{l}9.44 \\
9.14\end{array}$ & - & - \\
\hline & Fixed area plot & 10.19 & 0.22 & 4.32 & & \\
\hline
\end{tabular}

Table 2. The percentage of species composition in the fixed-area plot and variable-area plot

\begin{tabular}{c|c|c|c|c|c|c|c|c|c}
\hline $\begin{array}{c}\text { Type of } \\
\text { plot } \\
\text { area }\end{array}$ & $\begin{array}{c}\text { Carpinus } \\
\text { betulus }\end{array}$ & $\begin{array}{c}\text { Quercus } \\
\text { petraea }\end{array}$ & $\begin{array}{c}\text { Acer } \\
\text { copmestre }\end{array}$ & $\begin{array}{c}\text { Acer } \\
\text { monspessulanum }\end{array}$ & $\begin{array}{c}\text { Quercus } \\
\text { macranthera }\end{array}$ & $\begin{array}{c}\text { Cornus } \\
\text { mas }\end{array}$ & $\begin{array}{c}\text { Prunus } \\
\text { avium }\end{array}$ & $\begin{array}{c}\text { Taxus } \\
\text { baccata }\end{array}$ & $\begin{array}{c}\text { Euonymus } \\
\text { sp }\end{array}$ \\
\hline $\begin{array}{c}\text { Variable } \\
\text { area plot }\end{array}$ & 74.4 & 12.9 & 5.1 & 0.9 & 4 & 0.1 & 2.2 & 0.2 & 0.1 \\
\hline $\begin{array}{c}\text { Fixed } \\
\text { area plot }\end{array}$ & 76.6 & 11.3 & 5.3 & 1.3 & 3.1 & 0.3 & 1.3 & 0.6 & 0.3 \\
\hline
\end{tabular}

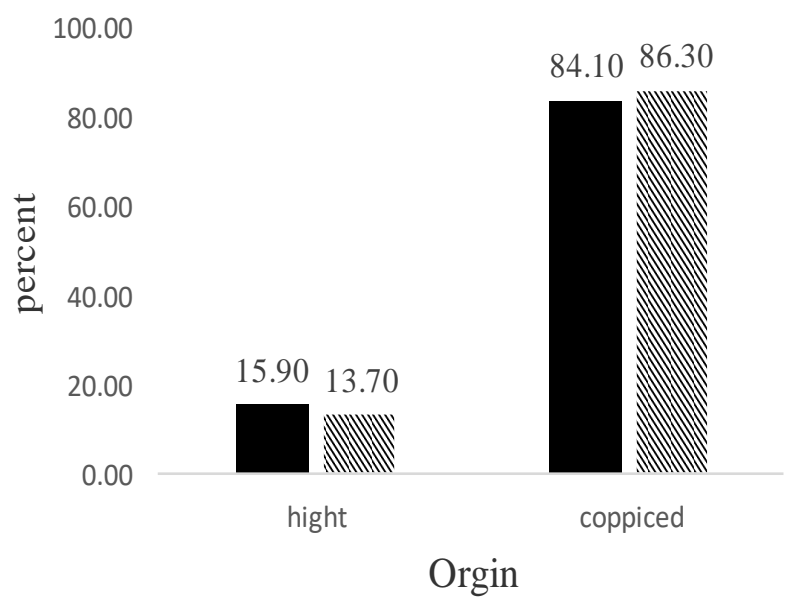

Figure 2. The origin of the stands in the fixed-area plot and the Variable-area plot 


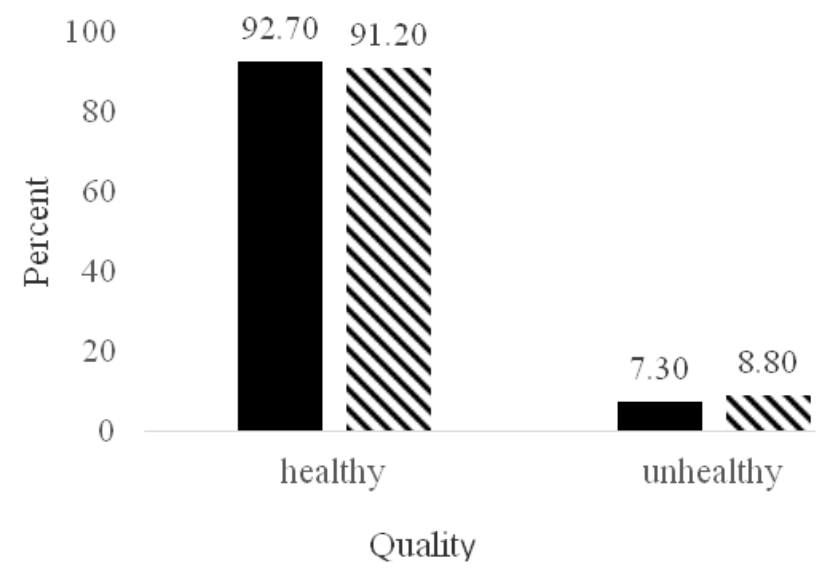

Figure 3. Health of the stems in the fixed-area and variable-area sample plots

Table 3. Comparison of qualitative characteristics of the stand in the two methods using Chi-square test

\begin{tabular}{c|c|c|c}
\hline Variables & Chi-square & Degree of freedom & Significance \\
\hline Percentages of mixture & 9.8 & 8 & $0.28^{\text {ns }}$ \\
Origin & 2.197 & 1 & $0.12^{\text {ns }}$ \\
Quality of species & 1.805 & 1 & $0.179^{\text {ns }}$ \\
\hline
\end{tabular}

\section{Sampling time}

Comparison of average sampling time in the two methods showed that there was a significant difference between the two inventory methods at the 5\% level (Table 4) and the recording time of the fixed-area plot was significantly higher than the recording time associated with the variable-area plot.

Table 4. Comparison of plot sampling time for two methods

\begin{tabular}{c|c|c|c|c}
\hline Variables & Fixed area plot & Variable area plot & $\mathbf{t}$ & Significance \\
\hline $\begin{array}{c}\text { Mean sampling time for } \\
\text { each plot (second) }\end{array}$ & $706.10(20.24)$ & $485.91(14.56)$ & 8.83 & $0.000^{*}$ \\
\hline
\end{tabular}

The significance is at $5 \%$ and the numbers in brackets indicate the standard error

\section{Evaluation of the two inventory methods using the $(E \%)^{2} \times T$ index}

The evaluation of the two inventory methods, taking into account the time and accuracy of the inventory (Equation 4), showed that the calculated values of this index for the variables of volume and basal area per hectare were less in the sampling method with variable area (Table 5).

Table 5. Comparison of two methods by using the $(E \%)^{2} \times T$ index

\begin{tabular}{c|c|c}
\hline Variables & Fixed area plot & Variable area plot \\
\hline Volume $(\mathrm{m} 3 / \mathrm{ha})$ & 118780.77 & 36778.50 \\
Basal area $(\mathrm{m} 2 / \mathrm{ha})$ & 88573.18 & 31253.92 \\
\hline
\end{tabular}




\section{Species diversity}

Mean and standard error of species richness, evenness and Shannon Wiener diversity and Simpson species diversity index of forest stands are shown in Table 6.

Although the evenness index and Simpson diversity derived from variable-area plots were higher than fixed-area plots and the species richness index and Shannon-Weiner species diversity index were higher in fixed-area plots, the t-test did not show a significant difference in the mean of different indices between the two methods $(\alpha=5 \%)$.

Table 6. Comparison of species diversity of the studied stand with t test results

\begin{tabular}{c|c|c|c|c}
\hline Variable & Fixed area plot & Variable area plot & $\mathbf{t}$ & Significance \\
\hline Richness & $2.79(0.16)$ & $2.40(0.11)$ & 1.960 & $0.52^{\mathrm{ns}}$ \\
Simpson diversity indices & $0.32(0.03)$ & $0.33(0.03)$ & -0.125 & $0.9^{\mathrm{ns}}$ \\
Shannon diversity indices & $0.58(0.052)$ & $0.55(0.045)$ & 0.396 & $0.69^{\mathrm{ns}}$ \\
Shannon evenness index & $0.51(0.043)$ & $0.58(0.043)$ & -1.108 & $0.27^{\mathrm{ns}}$ \\
\hline
\end{tabular}

n.s: The difference is not significant

\section{Discussion}

In this research, the fixed-area and Relascope sampling methods were used (for the first time in Arasbaran forests) to obtain quantitative and qualitative characteristics and species diversity indices. Different stand characteristics can be used as indicators of management practices in forests. Meantime, some stand characteristics are sensitive to the measurement method (e.g., volume, quadratic mean diameter and small stem density and basal area); while others are less sensitive (Misik et al., 2013: Rice et al., 2014). The results showed that the estimated quantitative parameters of the forests in this research were similar to the other studies conducted in the same forest stand (Alijanpour et al., 2003, 2009, 2011; Moradi et al., 2015). However, there were significant differences between the two methods regarding DBH, basal area at breast height per hectare and volume per hectare values. These results were consistent with existing literature (Fallah et al., 2000; Sadiqi et al., 2014; Lowell, 1997; Rios et al., 2000; Motz et al., 2010; Pique et al., 2011).

In terms of accuracy of estimating quantitative characteristics, the results showed that the standard error of estimation for average volume per hectare, basal area per hectare and number per hectare when using Relascope were less than those of sampling method with a circular fixed-area plot. More accurate estimations were made regarding basal area at the breast height and volume per hectare by variable-area plot (Relascope) method in comparison to fixed-area sampling method. In addition, in a study the methods were used to estimate variables including basal area at breast height, density, and diameter distribution of trees. It has been shown that in multi-layered habitats and semi high-density forests, the Relascope had more precision in estimating basal area than density (Pique et al., 2011). It has been suggested that the precision of measurements made by Relascope in surveying the basal area at breast height per hectare, volume per hectare and $\mathrm{DBH}$ was generally higher than that of circular sampling method (Druszcz et al., 1995).

In the investigation of qualitative characteristics such as species composition percentage, species origin and stem health, the results of the present study were 
consistent with the findings of the other researchers conducted in the same region (Amir ghasemi, 2001; Alijanpour et al., 2007; Moradi et al., 2015). Regarding the less measurement time using Relascope method, sampling method with variable-area plots (Relascope) for examining the species composition percentage and the origin and quality of the stems is suggested. Average time of sampling in fixed-area method was significantly higher than that of variable-area sampling method which was in good accordance with more recent report by Portela et al. (2016). Fallah et al. (2000) and Sadiqi et al. (2014) also reported the similar results. In determining the optimum method of sampling in Arasbaran forests stands, Alijanpour et al. (2003) showed that the average recording time of circular plots, rectangular and line samples were significantly different from each other and they reported that the time taken for line sampling was less than others.

In calculating the Shannon species diversity, Simpson species diversity and evenness, there was no significant difference between the two sampling methods. In this regard, other studies have shown that the accuracy of basal area and diversity indices were also similar (Motz et al., 2010). Moreover, by comparing the circle sample and distance methods in estimating diversity indices, the distance approach has been proposed for forest sampling strategies (Kint et al., 2004). Some researchers have introduced variable-area sampling for surveying species richness due to its speed and accuracy (Potela et al., 2016).

\section{Conclusion}

According to $(\mathrm{E} \%)^{2} \times$ index (Hush et al., 1982), It is concluded that for determining the characteristics of the basal area at breast height and volume per hectare, the sampling method with variable area was more appropriate regarding the standard error of estimation percentage and cost. In addition, due to the fact that there was no significant difference between the two methods for determining species diversity, using the Relascope could be suggested to estimate some quantitative characteristics as well as richness and diversity indices of the Arasbaran forests.

\section{REFERENCES}

[1] Alijanpour, A., Zobeiri, M., Marvi Mohajer, M. R., Zargham, N. (2003): An investigation of the best statistic sampelling method in forests of Arasbaran. - Iranian Journal of Natural Resources 56: 397-406 (in Persian).

[2] Alijanpour, A., Eshaghi Rad, J., Banj Shafiei, A. (2009): Investigation and comparison of two protected and non-protected forest stands regeneration diversity in Arasbaran. Iranian Journal of Forest 1: 209-217 (in Persian).

[3] Alijanpour, A., Eshaghi Rad, J., Banj Shafiei, A. (2011): Effect of physiographical factors on -qualitative and quantitative characteristics of Cornus mas L. in Arasbaran forests. Iranian Journal of Forest and Poplar Research 19: 396-407 (in Persian).

[4] Amir Ghasemi, F., Sagheb Talebi, K., Dargahi, D. (2001): Investigation of the natural resurrection structure of Arasbaran forests. - Forestry and Rangeland Research Institute 6: 1-16 (in Persian).

[5] Avery, T. E., Burkhart, H. E. (2015): Forest Measurements. - Waveland Press, New York.

[6] Barabesi, L., Fattorini, L. (1999): Bitterlich sampling estimators of diversity indexes. Statistica Applicata 11: 452-462. 
[7] Bitterlich, W. (1984): The Relascope Idea. Relative Measurements in Forestry. Commonwealth Agricultural Bureau, Slough.

[8] Druszcz, J., Machado, S., Nakajima, Y., Robeto, N., Hosokawa, T. (2015): Efficiency of the bitterly points sampling and method of fixed area sampling with structural variation in Pinus tea plantation. - Floresta 45: 523-534.

[9] Ducey, M. J. (1999): What expansion factor should be used in binned probability proportional to size sampling? - Canadian Journal of Forest Research 29: 1290-1294.

[10] Eshaghi Rad, J., Zobeiri, M., Sobhani, H., Zanganh, P. H. (2003): A comparison of randomized-systematic sampling with circle shape plot and transect method based on precision and cost, (case study in Sorkhedizeh of Kermanshah). - Iranian Journal of Natural Resources 56: 383-396 (in Persian).

[11] Fallah, A., Zobeiri, M., Nameraniyan, M. (2000): Comparison of sampling with fixed sampled area area and variable sample area in north oak forests (Lough Gorgan). Pazhohesh and Sazandegi 47: 64-68 (in Persian).

[12] Hassanzad Navroodi, I., Zarkami, R., Basati, M., Mohammadi Limaei, S. (2015): Quantitative and qualitative characteristics of Persian oak along altitudinal gradation and gradient (Case study: Ilam province, Iran). - Journal of Forest Science 61: 297-305 (in Persian).

[13] Henttonen, H., Kangas, A. (2015): Optimal plot design in a multipurpose forest inventory. - Forest Ecosystems 31: 2-14.

[14] Husch, B., Miller, C. I., Beers., T. W. (1982): Forest Mensuration. - Roland Press, New York.

[15] Islam, A., Hoseini, S. M. T., Sagheb-Talebi, K. (2015): Investigation stem number in the first diameter class for obtaining sustainable stands considering close to nature silviculture (case study: Shamushak forest, Golestan province). - Journal of Wood \& Forest Science and Technology 23: 111-124 (in Persian).

[16] Kint, V., Wulf, R., Noel, L. (2004): Evaluation of sampling methods for the estimation of structural indices in forest stands. - Ecological Modeling 180: 461-476.

[17] Lowell, K. E. (1997): An empirical evaluation of spatially based forest inventory samples. - Canadian Journal of Forest Research 27: 352-360.

[18] Misik, T., Varga, K., Veres, I., Karasz, I., Tothmeresz, B. (2013): Long-term response of understory cover, basal area and diversity to stand density in a mixed oak forest on the Síkfókút plot in Hungary. - Journal of Forest Science 59: 319-327.

[19] Mohammad Zadeh, A., Basiry, R., Torahi, A. A., Dadashian, R., Elahian, M. (2014): Evaluation of biodiversity of plant species in Arasbaran area using non-parametric measures with respect to topographic factor of slope: a case study of aquifers land of Ilgina and Kaleibar rivers. - Plant Researcher 27: 728-741 (in Persian).

[20] Moradi Dirmandrik, S., Ramezani Kakroudi, E., Alijanpour, A., Banj Shafiei, A. (2015): Quantitative and qualitative characteristics of Arasbaran Forest Protected Area in slope gradient classes. - Forest Research and Development 1: 1-15 (in Persian).

[21] Motz, K., Sterba, H., Pommerening, A. (2010): Sampling measures of tree diversity. Forest Ecology and Management 26: 1985-1996.

[22] Nakajima, N., Yoshida, S., Imanaga, M. (1995): Comparison among four ground-survey methods as a continuous forest inventory system for forest management. - Journal of the Japanese Forestry Society 77: 573-580.

[23] Nath, C., Pelissier, R., Garcia, C. (2009): Comparative efficiency and accuracy of variable area transects versus square plots for sampling tree diversity and density. Agroforestry Systems 79: 223-236.

[24] Parker, K. R. (1979): Density estimation by variable area transect. - Journal of Wildlife Management 43: 484-492.

[25] Pique, M., Obon, B., Conde, S., Saura, S. (2011): Comparison of Relascope and fixedradius plots for the estimation of forest stand variables in northeast Spain: an inventory simulation approach. - European Journal of Forest Research 130: 851-859. 
[26] Portela, R., Pires, A., Guedes, M., Marros, E. (2016): Species richness and density evaluation for plants with aggregated distribution: fixed plot and variable area method. Journal of Plant Ecology 10: 765-770.

[27] Pretzsch, H. (1997): Analysis and modelling of spatial stand structures. Methodological considerations based on mixed beech-larch stands in Lower Saxony. - Forest Ecology and Management 97: 237-253.

[28] Rice, B., Weiskittel, A., Wagner, R. (2014): Efficiency of alternative forest inventory methods in partially harvested stands. - European Journal of Forest Research 133: 261272.

[29] Rios, N., Acosta, V., de Benitez, C. G., Pece, M. (2000): Comparison between sampling methods. - Forest Systems 9: 45-57.

[30] Sadiqi, S., Bonyad, A. A., Abkar, H. K., Abdolahpour, J. (2014): Comparison of sampling with fixed sampled area and variable sample area in estimated basal area (Case study: Armordeh forest. - National Conference on Sustainable Development of Renewable Natural Resources, Baneh (in Persian).

[31] Sagheb Talebi, K., Sajedi, T., Yazdiyan, F. (2005): A Look at Iran's Forests. - Forestry and Rangeland Research Institute, Tehran (in Persian).

[32] Sheil, D., Ducey, M. J., Sidiyasa, K., Samsoedin, I. (2003): A new type of sample unit for the efficient assessment of diverse tree communities in complex forest landscapes. Journal of Tropical Forest Science 15: 117-135.

[33] Su, D., Yu, D., Zhou, L., Xie, X., Liu, Z., Dai, L. (2012): Differences in the structure, species composition and diversity of primary and harvested forests on Changbai Mountain. Northeast China. - Journal of Forest Science 56: 285-293.

[34] Zare, L., Erfanifard, S. Y., Taghvaiand, M., Kariminejad, N. (2016): Efficiency of distance sampling methods in estimation of biometric characteristics of wild Pistachio open stands in Zagros. - Journal of Wood and Forest Science and Technology 23: 125144.

[35] Zobeyri, M. (2007): Forest Inventory (Measurement of Tree and Forest). - Tehran University Press, Tehran (in Persian). 